\title{
Evaluation of the Effect of the COVID -19 'Lockdown Process' on the Clinical and Metabolic Parameters of Obese Patients: A Single Center Cross-Sectional Study
}

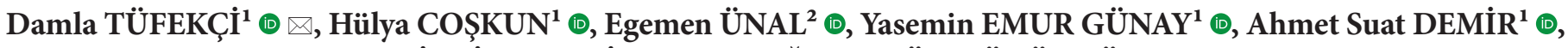

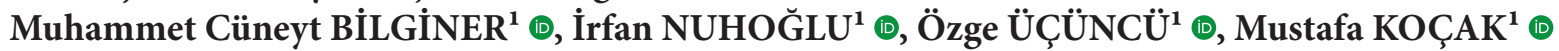 \\ ${ }^{1}$ Karadeniz Technical University Faculty of Medicine, Department of Endocrinology and Metabolism, Trabzon, Turkey \\ ${ }^{2}$ Ankara Yıldırım Beyazıt University Faculty of Medicine, Department of Public Health, Ankara, Turkey
}

Cite this article as: Tüfekçi D et al. Evaluation of the Effect of the Covid -19 'Lockdown Process' on the Clinical and Metabolic Parameters of Obese Patients: A Single Center CrossSectional Study. Turk J Diab Obes 2021;2: 186-192.

\begin{abstract}
Aim: The COVID-19 "lockdown process" can cause weight gain due to sedentary lifestyle, dietary and sleep disturbances. In this study, we aimed to determine clinical and metabolic effects of weight change in obese patients caused by the quarantine.

Material and Methods: This study included 44 patients with a BMI of $30 \mathrm{~kg} / \mathrm{m}^{2}$. In the study, patients' pre-quarantine metabolic parameters were obtained from hospital records. The metabolic parameters of the patients were measured again after quarantine. Patients were questioned about weight tracking, eating habits, exercise, and the need for hospital admission during quarantine.

Results: Of the patients $(n=44), 72.7 \%$ were women and mean age was 39.9 \pm 13.9 (18.0-61.0) years. The BMI of patients was 36.0 (30.7$46.0) \mathrm{kg} / \mathrm{m}^{2}$ and $27.3 \%(\mathrm{n}=12)$ of patients were morbidly obese. During the quarantine, patients' weight $(\mathrm{p}<0.001)$ and $\mathrm{BMI}(\mathrm{p}<0.001)$ increased. Patients' dietary compliance changed from $27.3 \%$ to $13.6 \%(\mathrm{p}=0.109)$ and home exercise from $29.5 \%$ to $31.8 \%$ ( $\mathrm{p}=0.999$ ). $68.2 \%$ of patients tracked weight and $52.3 \%$ experienced increased appetite. Obese patients tracked their weight significantly more often than morbidly obese patients $(p=0.027)$. Weight gain wasn't associated with dietary compliance $(p=0.609)$ and exercise $(p=0.633)$. A significant increase in patients' glucose, insulin, HOMA- IR and cholesterol ( $\mathrm{p}<0.001$ for each) was observed.

Conclusion: In this study, it was observed that the COVID -19 "Lockdown Process" increased BMI in obese patients regardless of diet and exercise. Consequently, a significant worsening was observed in obese patients' insulin resistance and lipid parameters. Active follow-up strategies for obese patients in possible quarantines can prevent the negative consequences.
\end{abstract}

Keywords: COVID-19, Obesity, Quarantine

\section{COVID-19 'Evde Kal’ Sürecinin Obez Hastalarının Klinik ve Metabolik Parametreleri Üzerine Etkisinin Değerlendirilmesi: Tek Merkez Kesitsel Çalışma}

ÖZ

Amaç: COVID-19'un 'Evde Kal' süreci obezite hastalarında hareketsiz bir yaşama, beslenme ve uyku bozukluğuna bağlı olarak kilo artışına neden olabilir. Biz bu çalışmada; karantina sürecinin obezite hastalarında oluşturduğu kilo değişiminin klinik ve metabolik etkilerini tespit etmeyi amaçladık.

Gereç ve Yöntemler: Bu çalışmaya kliniğinimize ayaktan başvuran VKİ $\geq 30 \mathrm{~kg} / \mathrm{m}^{2}$ olan 44 hasta dâhil edildi. Çalışmada karantina öncesi tarafımızca takip edilen hastaların metabolik parametreleri kayıtlı dosyalardan elde edildi. Bu hastaların karantina sonrası polikliniğimize ilk başvuruları sırasındaki metabolik parametreleri tekrar ölçüldü. Ayrıca hastaların karantina sürecindeki kilo takibi, beslenme alışkanlıkları, fiziksel aktiviteleri yüz yüze sorgulandı.

ORCID: Damla Tüfekçi / 0000-0001-5928-873X, Hülya Coşkun / 0000-0002-7837-4251, Egemen Ünal / 0000-0002-9939-9191, Yasemin Emur Günay / 0000-0002-0645-2070, Ahmet Suat Demir / 0000-0002-2282-3820, Muhammet Cüneyt Bilginer / 0000-0002-7652-7648, İrfan Nuhoğlu / 0000-0003-0650-3242, Özge Üçüncü / 0000-0003-4658-7778, Mustafa Koçak / 0000-0002-8269-2869 
Bulgular: Hastaların ( $\mathrm{n}=44) \% 72,7$ 'si kadın, \%27,3'ü erkeklerden oluşmaktaydı. Hastaların ortalama vücut kütle indeksleri (VKİ) $36(30,70-46,00) \mathrm{kg} / \mathrm{m}^{2}$ olup hastaların \%27,3’ü $(\mathrm{n}=12)^{\prime} \ddot{\mathrm{u}}$ morbid obezdi. Karantina sürecinde hastaların kilo (p<0,001) ve VKI ( $\mathrm{p}<0,001)^{\prime}$ inde artış olduğu görüldü. Hastaların diyet uyumunun \%27,3'ten \%13,6’ya $(\mathrm{p}=0,109)$ düştüğü, ev içi egzersiz durumunun ise \%29,5 iken \%31,8 ( $\mathrm{p}=0.999)$ olduğu ayrıca \%68,2'sinin kilo takibi yaptığı, \%52,3'ünün iştah artışı yaşadığı tespit edildi. Obez hastaların morbid obezlere kıyasla anlamlı şekilde daha fazla kilo takibi yaptıkları görüldü $(\mathrm{p}=0,027)$. Hastaların kilo artışı diyet uyumu ( $\mathrm{p}=0,609)$ ve egzersiz $(p=0,633)$ ile ilişkili değildi. Karantina sürecinde hastaların glukoz $(p=0,001)$, insülin $(p<0,001)$, homa-IR ( $<<0,001)$ ve kolesterol ( $\mathrm{p}<0,001)$ değerlerinde artış görüldü.

Sonuç: Bu çalışmada 'Evde Kal Süreci’nin obez hastaların beslenme alışkanlığı ve egzersiz durumlarından bağımsız olarak VKİ'inde artış olduğu görülmüştür. Bununla ilişkili olarak obez hastaların insülin direnci ve lipid parametrelerinde belirgin bozulma gözlenmiştir. Bundan sonra olası karantina süreçlerinde obez hastalar için daha aktif takip stratejilerinin planlanması bu süreçte hastaların yaşadığı olumsuz sonuçların önüne geçebilir.

Anahtar Sözcükler: COVID-19, Obezite, Karantina

\section{INTRODUCTION}

Obesity is defined as excessive fat accumulation in the body as a result of high energy intake. The World Health Organization (WHO) reports that obesity will be the most important health problem of the $21^{\text {st }}$ century (1). It was reported that the prevalence of obesity and morbid obesity increased by $42 \%$ from 2017 to 2018 , and this was $9 \%$ more than the increase in the transition from 2009 to 2010 (2). Obesity is associated with significant increases in morbidity (including diabetes mellitus, hypertension, dyslipidemia, heart disease, cerebrovascular accidents, sleep apnea, and cancer) and mortality.

The morbidity and mortality statistics of COVID -19 appear to disproportionately affect the vulnerable population with pre-existing chronic diseases such as diabetes, heart disease, obesity and severe obesity. In particular, individuals with obesity have high rates of hospitalization and are at high risk of disease and mortality (3). In particular, individuals with obesity have a high rate of hospitalization and are at risk for severe illness and mortality (3). Given the effects of obesity on lung function and inflammation, the impact of COVID - 19 on people with obesity is not surprising $(4,5)$. However, it is believed that mandatory lockdown processes such as quarantine may affect mental health and finances in addition to physical health in vulnerable populations such as obese people.

It is not known how the COVID -19 outbreak affects weight management, health behaviors, and psychosocial health, particularly in people with obesity. Because of the increase in obesity-related behaviors due to the COVID -19 pandemic, it is very important that health care is accessible to obese patients. Because of the increase in obesity-related behaviors due to the COVID -19 pandemic, it is very important that obese patients have access to health care services.
In our study, it was planned to evaluate the clinical and metabolic effects of quarantine period on obese patients in our country.

\section{MATERIALS and METHODS}

This study included 44 patients who were followed up in Karadeniz Technical University, Endocrinology and Metabolic Diseases clinic for obesity (BMI $\geq 30 \mathrm{~kg} / \mathrm{m}^{2}$ ). "G POWER" software program was used to determine the minimum sample size. The minimum sample size determined as " 42 ", with $90 \%$ power (1- $\beta$ ), 0.05 alpha error and 0.530 effect size according to literature review.

Patients who were overweight (BMI 25-29.9) were not included in the analysis; all patients were obese. Follow-up measurements and biochemical data from patients followed up in our clinic before March 11, 2020, the date the first case was identified in Turkey, were scanned. The same patients were assessed individually on their first admission to our outpatient clinic after quarantine. At the outpatient visits after quarantine, dietary habits, exercise status, weight gain, sleep patterns, need for hospitalization, and whether patients had an infection were recorded with a questionnaire we prepared after an approximately 30-minute face-to-face oral interview. The questions were asked again so that the patients' answers were confirmed twice. In the diet compliance questionnaire, those who had low or partial compliance were included in the diet compliance group. Partial walking and exercises that can be done as home exercises apart from daily activities, or activities they can do with any sports equipment were questioned. Sleep behavior was questioned in detail about times of falling asleep and waking up, change in time of falling asleep, and difficulty in falling asleep or frequent waking up, and recorded as change in sleep behavior according to the responses. In addition, the need to wake up at night and eat was questioned. The information in the file was updated by questioning their chronic illnesses and medications taken. Patients who had a detailed physical exam- 
ination were weighed on the Tanita BC-418- MA machine. After the patients rested for 15 minutes, blood pressure was measured in the sitting position using the Omron M3 HEM -7155-E digital arm sphygmomanometer. Biochemical parameters (glucose, insulin, creatinine, ALT, Homa- IR, lipid profile, thyroid function tests) were analyzed in the morning blood after 8 hours of fasting. Glucose $(70-100 \mathrm{mg}$ / dl), ALT (0-45 U / L), creatinine (0.51-0.95 mg / dl), TSH (0.41 - 6.80 mIU / L), Free T4 (0.57 - 1.24 ng / dL), insulin $(<29.1 \mathrm{mIU} / \mathrm{L})$, total cholesterol $(120-200 \mathrm{mg} / \mathrm{dl})$, triglycerides (50 - $150 \mathrm{mg} / \mathrm{dl}), \mathrm{HDL}$ cholesterol $(45-65 \mathrm{mg} /$ dl), LDL cholesterol ( $<160 \mathrm{mg} / \mathrm{dl})$, HOMA- IR $(<2.5)$ were evaluated according to reference limits. Plasma glucose level was measured by hexokinase (Beckman Coulter AU5800) enzymatic reference method and insulin level was measured by the CLIA (chemiluminescent immunoassay) (Siemens immunoassay) method. HOMA- IR value was calculated using the formula fasting blood glucose $\times$ insulin / 405. Free T4 and TSH were measured using the chemiluminescence immunoassay (CLIA) method (Roche cobas e 411). Total cholesterol, triglycerides, LDL-C, HDL-C (Beckman Coulter AU 5800) were measured by enzymatic calorimetric method; ALT (Beckman Coulter AU 5800) by UV kinetic method and pyridoxal-5'-phosphatase and creatinine (Beckman Coulter AU 5800) by Jaffe calorimetric method.

Ethics Committee approval (number 24237859-608) was granted on 01.10.2020 and was in accordance with the Declaration of Helsinki (1964).

\section{Statistical Analysis}

The data obtained were analyzed using the statistical package program IBM-SPSS (version 22.0) in the computer environment. For descriptive statistics, number, percentage, mean, standard deviation, minimum, maximum, and median values were used. . In the study, after performing normality analyses with Kolmogorov-Smirnov and Shapiro-Wilk tests, we determined that our data sets have not normal distribution. So chi-square was used for categorical comparison of independent groups and Wilcoxon Test used for comparison of means of dependent groups. For statistical significance, $\mathrm{p} \leq 0.05$ was accepted.

\section{RESULTS}

$72.7 \%$ of the study group were female, $27.3 \%$ were male, and their mean age was $39.9 \pm 13.9$ (18.0-61.0) years. While $27.3 \%$ of subjects had dietary compliance before quarantine, this rate was found to be $13.6 \%$ during quarantine (p: 0.109 ). While the rate of indoor exercise before quarantine was $29.5 \%$, it was observed to be $31.8 \%$ during the quarantine period ( $\mathrm{p}=0.999)$. One person ( $2.3 \%)$ in the study group reported receiving medical and surgical treatment for obesity. (Table 1)
During quarantine, $68.2 \%$ of subjects reported tracking their weight, $52.3 \%$ experienced an increase in appetite, and $40.9 \%$ reported a change in their sleep patterns. The mean BMI of the study group was $36.5 \pm 4.2(30.7-46.0)$, and no correlation was found between BMI and systolic and diastolic blood pressure values ( $\mathrm{p}=0.680$ and $\mathrm{p}=0.767$, respectively). No correlation was found between dietary compliance during quarantine, home exercise status, and presence of weight gain and BMI $(\mathrm{p}=0.751, \mathrm{p}=0.714, \mathrm{p}=0.661$, respectively).

While the weight, BMI, Homa-IR, glucose, insulin, cholesterol, triglycerides (TG) LDL-C, HDL-C and TSH values of the study group increased after quarantine, ALT, creatinine and T4 values did not change (Table 2).

$86.4 \%(n=26)$ of individuals in the study group reported gaining weight during quarantine. $95.7 \%(\mathrm{n}=22)$ of individuals with increased appetite during the quarantine period gained weight (Table 3 ).

Table 1: Distribution of some sociodemographic characteristics of the study group.

\begin{tabular}{|c|c|c|}
\hline \multicolumn{2}{|l|}{ Characteristics } & $\begin{array}{c}\text { Median } \\
\text { (Min-Max) }\end{array}$ \\
\hline \multicolumn{2}{|l|}{ Age (years) } & $38.5(18.0-61.0)$ \\
\hline \multicolumn{2}{|l|}{ Height $(\mathrm{cm})$} & $160.5(147.0-186.0)$ \\
\hline \multicolumn{2}{|l|}{ Weight (kg) } & $93(70.0-140.0)$ \\
\hline \multicolumn{2}{|l|}{ BMI $\left(\mathrm{kg} / \mathrm{m}^{2}\right)$} & $36.0(30.7-46.0)$ \\
\hline & & n (\%) \\
\hline \multirow{2}{*}{ Gender } & Female & $32(72.7)$ \\
\hline & Male & $12(27.3)$ \\
\hline \multirow{6}{*}{ Medications used } & None & $20(45.4)$ \\
\hline & LT4 & $12(27.3)$ \\
\hline & Anti-hypertensive & $7(15.9)$ \\
\hline & PPI & $1(2.3)$ \\
\hline & Anti-depressant & $3(6.8)$ \\
\hline & Metformin & $1(2.3)$ \\
\hline \multirow{4}{*}{ Comorbidities } & None & $18(40.9)$ \\
\hline & Hypothyroid & $14(31.8)$ \\
\hline & HT & $7(15.9)$ \\
\hline & Other & $5(11.4)$ \\
\hline \multirow{2}{*}{$\begin{array}{l}\text { Medical treatment } \\
\text { for obesity }\end{array}$} & No & $43(97.7)$ \\
\hline & Yes & $1(2.3)$ \\
\hline \multirow{2}{*}{$\begin{array}{l}\text { Surgical treatment } \\
\text { for obesity }\end{array}$} & No & $43(97.7)$ \\
\hline & Yes & $1(2.3)$ \\
\hline
\end{tabular}


Table 2: Comparison of weight, BMI and laboratory values before and after quarantine.

\begin{tabular}{lccc}
\hline & $\begin{array}{c}\text { Baseline value } \\
\text { Median (min-max) }\end{array}$ & $\begin{array}{c}\text { Final value } \\
\text { Median (min-max) }\end{array}$ & $\mathbf{p}$ \\
\hline Weight $(\mathbf{k g})$ & $89.0(69.0-136.0)$ & $93.0(70.0-140.0)$ & $<\mathbf{0 . 0 0 1}$ \\
\hline BMI (kg/m $\mathbf{m}^{2}$ & $33.7(30.0-45.0)$ & $36.0(30.7-46.0)$ & $<\mathbf{0 . 0 0 1}$ \\
\hline HOMA-IR & $3.3(1.8-10.4)$ & $4.10(1.6-10.8)$ & $<\mathbf{0 . 0 0 1}$ \\
\hline Glucose & $90.5(69.0-114.0)$ & $93.5(80.0-119.0)$ & $\mathbf{0 . 0 0 1}$ \\
\hline Insulin & $15.55(0.7-57.0)$ & $17.85(7.9-41.4)$ & $<\mathbf{0 . 0 0 1}$ \\
\hline Cholesterol & $204.50(114.0-332.0)$ & $220.50(126.0-320.0)$ & $<\mathbf{0 . 0 0 1}$ \\
\hline TG & $128.5(60.0-368.0)$ & $138.0(64.0-367.0)$ & $\mathbf{0 . 0 0 9}$ \\
\hline LDL & $129.0(50.0-186.0)$ & $137.5(42.0-238.0)$ & $<\mathbf{0 . 0 0 1}$ \\
\hline HDL & $48.5(35.0-135.0)$ & $49.0(32.0-138.0)$ & $\mathbf{0 . 0 0 9}$ \\
\hline ALT & $21.0(9.0-200.0)$ & $19.5(10.0-207.0)$ & 0.127 \\
\hline Creatinine & $0.6(0.4-0.9)$ & $0.7(0.4-0.9)$ & 0.240 \\
\hline T4 & $0.9(0.5-1.3)$ & $0.9(0.5-3.0)$ & 0.130 \\
\hline TSH & $1.9(0.02-5.8)$ & $1.9(0.01-17.7)$ & $\mathbf{0 . 0 3 1}$ \\
\hline
\end{tabular}

Analyzed with Wilcoxon Signed Rank Test.

Table 3: Assessment of factors affecting weight change during the quarantine.

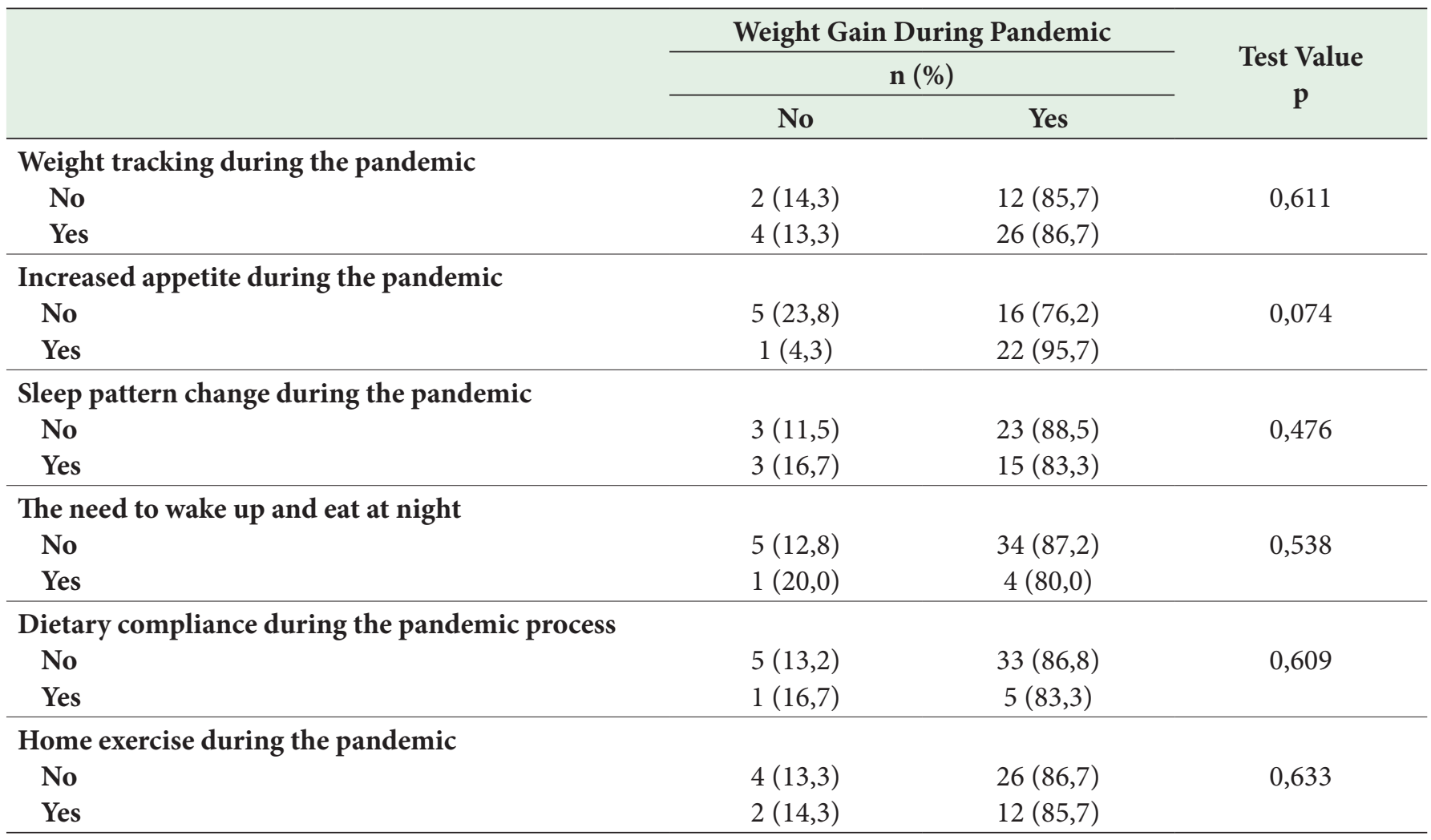

In the study, 27.3\% $(\mathrm{n}=12)$ of individuals were classified as morbidly obese based on their BMI values. When the health behavior and symptoms of these individuals during the quarantine period were examined, morbid obesity was found in half of the individuals who did not track their weight during the quarantine period. It was observed that the behavior of not tracking weight during the quarantine period was more common in morbidly obese individuals $(\mathrm{p}=0.027)$. It was found that behaviors such as increased appetite, change in sleep patterns, need to wake up at night and eat, compliance 
Table 4: Distribution of morbidly obese and obese patients' health behaviors and symptoms during the quarantine period.

\begin{tabular}{|c|c|c|c|}
\hline & $\begin{array}{c}\text { Obese } \\
\left(\mathrm{BMI} 30-39.9 \mathrm{~kg} / \mathrm{m}^{2}\right)\end{array}$ & $\begin{array}{l}\text { Morbidly obese } \\
\left(\mathrm{BMI} \geq 40 \mathrm{~kg} / \mathrm{m}^{2}\right)\end{array}$ & \multirow{3}{*}{$\begin{array}{c}\text { Test Value } \\
\text { p }\end{array}$} \\
\hline & \multicolumn{2}{|c|}{$\mathrm{n}(\%)$} & \\
\hline & No & Yes & \\
\hline \multicolumn{4}{|l|}{ Weight tracking during the pandemic } \\
\hline No & $7(50.0)$ & $7(50.0)$ & 0.027 \\
\hline Yes & $25(83.3)$ & $5(16.7)$ & \\
\hline \multicolumn{4}{|c|}{ Increased appetite during the pandemic } \\
\hline No & $13(61.9)$ & $8(38.1)$ & 0.230 \\
\hline Yes & $19(82.6)$ & $4(17.4)$ & \\
\hline \multicolumn{4}{|c|}{ Sleep pattern change during the pandemic } \\
\hline No & $18(69.2)$ & $8(30.8)$ & 0.393 \\
\hline Yes & $14(77.8)$ & $4(22.2)$ & \\
\hline \multicolumn{4}{|l|}{ The need to wake up and eat at night } \\
\hline No & $28(71.8)$ & $11(28.2)$ & 0.583 \\
\hline Yes & $4(80.0)$ & $1(20.0)$ & \\
\hline \multicolumn{4}{|c|}{ Dietary compliance during the pandemic process } \\
\hline No & $27(71.1)$ & $11(28.9)$ & 0.471 \\
\hline Yes & $5(83.3)$ & $1(16.7)$ & \\
\hline \multicolumn{4}{|l|}{ Home exercise during the pandemic } \\
\hline No & $22(73.3)$ & $8(26.7)$ & 0.583 \\
\hline Yes & $10(71.4)$ & $4(28.6)$ & \\
\hline \multicolumn{4}{|l|}{ Weight gain during the pandemic } \\
\hline No & $\begin{array}{c}5(83.3) \\
27(71.1)\end{array}$ & $11(28.9)$ & 0.471 \\
\hline
\end{tabular}

to diet, home exercise, weight gain during quarantine were similar between morbidly obese and non-morbidly obese individuals ( $\mathrm{p}>0.05$ for each) (Table 4).

\section{DISCUSSION}

As with other respiratory infections, there is an important relationship between COVID-19 and obesity. Studies have shown that the incidence of severe COVID-19 infection is increased in patients with obesity compared to normal weight patients (6). In a retrospective evaluation of 112 patients in Wuhan, it was found that patients with high BMI had a higher rate of critical illness than patients with normal BMI (7). In another study evaluating 1482 patients who required hospitalization for COVID -19, it was found that $89.3 \%$ of patients had comorbidities and obesity was the second most common condition after hypertension in these patients (8). Given the effects of obesity on lung function and inflammation, the impact of COVID -19 in obese individuals is not surprising $(4,5)$.

In addition to the association between obesity and risk of COVID -19 infection, it is suggested that the quarantine process may be important for obese patients. In a study evaluating 123 obese patients in the US, it was found that $69.6 \%$ of patients who stayed at home during quarantine did not reach their weight loss goals. There was a decrease in exercise duration (47.9\%) and intensity (55.8\%) of patients. In addition, $49.6 \%$ reported that food stocks increased and $61.7 \%$ reported eating behaviors that increased with stress (9). Obese patients were evaluated in this study regardless of their infection status. In this challenging quarantine process, it was observed that the weight $(\mathrm{p}<0.001)$ and BMI $(p<0.001)$ of obese patients who was included in our study, increased when their weight tracking and changes, dietary compliance and exercise status were assessed. While 27.3\% of patients had dietary compliance before quarantine, this rate decreased to $13.6 \%$ during the quarantine process $(\mathrm{p}=0.109)$. On the other hand, it was observed that the rate of home exercise increased slightly during the quarantine period (31.8\%) compared to the pre-quarantine period $(29.5 \%)(p=0.999)$. However, no relationship was found between dietary compliance and exercise rates and weight gain. The inability to obtain statistically significant results 
may be attributed to the limited number of patients enrolled in the study in a short period of time. Although the home exercise rates of the patients increased, the decrease in their daily routine activities may be associated with weight gain and worsening in metabolic parameters. However, patients were assessed face-to-face, and their measurements and questionnaires were recorded objectively. An online survey was not conducted.

In a study that examined the dietary habits and weight tracking of adults in Poland, it was found that 52\% of individuals had increased cravings for food and snacking, and this situation was more likely to be observed in overweight and obese individuals. In addition, about $30 \%$ of them gained weight, and it was observed that this situation was more likely to occur in obese and elderly people (10). In addition, about $30 \%$ of them gained weight, and it was observed that this was more likely to occur in obese and elderly people (10). In our study, it was found that only $13.6 \%$ of obese patients had diet compliance during the pandemic and more than half of the patients (52.3\%) experienced appetite increase. In our study, $27.3 \%$ of patients were morbidly obese and it was observed that morbidly obese people tracked less weight during quarantine. $(\mathrm{p}=0.027)$.

The change in daily routine (regular activities at home and at work), the reduction in social contacts and the physical limitations during quarantine led to disappointment (11). One study suggested that quarantine may increase psychological problems such as depression, anxiety, and post-traumatic stress disorder (12). Consequently, stress and depression may increase the need for high-calorie food consumption in humans (13). The stress environment and the quarantine process are likely to have a negative effect on body weight. In our study, $52.3 \%(n=23)$ of patients had increased appetite and $40.9 \%(n=18)$ had changes in sleep patterns. As noted in several studies, the stress and pressure of the quarantine period may be associated with increased appetite and sleep patterns. As an expected result, $95.7 \%$ of individuals who had an increased appetite during the pandemic had weight gain.

In an online survey study in Italy, it was observed that obese individuals experienced an average weight gain of $1.5 \mathrm{~kg}$ during the 1-month quarantine period. A relationship has been found between weight gain and low education level, and anxiety/depression (14). An average increase of $3.02 \mathrm{~kg}$ was also observed in the patients in our study.

In addition to the association between obesity and the risk of COVID -19 infection, it is suggested that the quarantine process may be important in obese patients in several ways. While obese people already isolate themselves and avoid social contact even under normal conditions and therefore have higher rates of depression, the quarantine process has created even more difficult conditions for the obese patient group. In our study, the potential impact of this period was objectively measured by assessing patients individually in the outpatient setting at the end of the process.

When comparing the biochemical evaluations before and after quarantine, a significant increase was found in glucose $(\mathrm{p}=0.001)$, insulin $(\mathrm{p}<0.001)$, Homa-IR $(\mathrm{p}<0.001)$ levels of the patients. In addition, a significant increase in lipid parameters of patients was observed, especially cholesterol $(p<0,001)$,TG $(p=0.009)$ and LDL $(p<0,001)$ levels after quarantine. As far as we know, in the literature, there is no similar study that evaluates the change in biochemical values of individuals after the quarantine process. However, because of the limited process, only a limited number of patients could be evaluated.

There are some limitations in our study. First of all, the limited number of patients makes our evaluation difficult. Also, our evaluation of diet compliance and exercise rates only with the verbal responses of the patients makes our results subjective.

This study has shown that "Lockdown Process" causes weight gain and an associated worsening of insulin resistance and lipid parameters in obese patients who did not have "COVID -19 " infection, regardless of their eating habits and physical activity. To the best of our knowledge, there is no similar study in the literature that evaluates the change in biochemical values of individuals after the quarantine process. However, studies with larger patient populations are needed to evaluate this important subject in detail.

\section{Acknowledgments}

None.

Author Contributions

Idea/Concept: Damla Tüfekçi, Hülya Coşkun, Yasemin Emur Günay, Design: Damla Tüfekçi, Hülya Coşkun, Yasemin Emur Günay, Control/Supervision: Mustafa Koçak,İrfan Nuhoğlu, M. Cüneyt Bilginer, Egemen Ünal, Data Collection and/or Processing: Damla Tüfekçi, Hülya Coșkun, Yasemin Emur Günay, Egemen Ünal, Analysis and/or Interpretation: Damla Tüfekçi, Hülya Coşkun, Egemen Ünal, Literature Review: Damla Tüfekçi, Hülya Coşkun, Writing: Damla Tüfekçi, Critical Review: Damla Tüfekçi, Mustafa Koçak, İrfan Nuhoğlu, References and Fundings: Damla Tüfekçi, Materials: Damla Tüfekçi.

\section{Conflict of Interest}

No conflicts of interest between the authors and / or family members of the scientific and medical committee members or members of the potential conflicts of interest, counseling, expertise, working conditions, share holding and similar situations in any firm. 


\section{Financial Support}

During this study, no financial or spiritual support was received neither from any pharmaceutical company that has a direct connection with the research subject, nor from a company that provides or produces medical instruments and materials which may negatively affect the evaluation process of this study.

\section{Ethical Approve}

This study has been approved by The Clinical Researches Ethical Committee of Karadeniz Technical Univercity (Number 946756/ 2021 ). Declaration of Helsinki was followed in this study design and report.

\section{REFERENCES}

1. World Health Organization. Obesity: Preventing and Managing the Global Epidemic. Geneva: The World Health Organization; 2000. Technical Report Series no. 894.

2. Hales CM, Carroll MD, Fryar CD, Ogden CL. Prevalence of obesity and severe obesity among adults: United States, 20172018. NCHS Data Brief. 2020;(360):1-8.

3. Richardson S, Hirsch JS, Narasimhan M, Crawford JM, McGinn T, Davidson KW; the Northwell COVID-19 Research Consortium, Barnaby DP, Becker LB, Chelico JD, Cohen SL, Cookingham J, Coppa K, Diefenbach MA, Dominello AJ, Duer-Hefele J, Falzon L, Gitlin J, Hajizadeh N, Harvin TG, Hirschwerk DA, Kim EJ, Kozel ZM, Marrast LM, Mogavero JN, Osorio GA, Qiu M, Zanos TP. Presenting characteristics, comorbidities, and outcomes among 5700 patients hospitalized with covid-19 in the New York City area. JAMA. 2020; 323(20):2052-2059.

4. Dietz W, Santos-Burgoa C. Obesity and its implications for COVID-19 mortality. Obesity (Silver Sipring).2020;28(6):1005.

5. Parameswaran K, Todd DC, Soth M. Altered respiratory physiology in obesity. Can Respir J. 2006;13(4):203-210.

6. Liu M, He P, Liu HG, Wang XJ, Li FJ, Chen S, Lin J, Chen P, Liu JH, Li CH. Clinical characteristics of 30 medical workers infected with new coronavirus pneumonia. Zhonghua Jie He He Hu Xi Za Zhi. 2020;43(0):E016.
7. Peng YD, Meng K, Guan HQ, Leng L, Zhu RR, Wang BY, He MA, Cheng LX, Huang K, Zeng QT. Clinical characteristics and outcomes of 112 cardiovascular disease patients infected by 2019-nCoV. Zhonghua Xin Xue Guan Bing Za Zhi. 2020;48(6):450-455.

8. Garg S, Kim L, Whitaker M, O'Halloran A, Cummings C, Holstein R, Prill M, Chai SJ, Kirley PD, Alden NB, Kawasaki B, Yousey-Hindes K, Niccolai L, Anderson EJ, Openo KP, Weigel A, Monroe ML, Ryan P, Henderson J, Kim S, ComoSabetti K, Lynfield R, Sosin D, Torres S, Muse A, Bennett NM, Billing L, Sutton M, West N, Schaffner W, Talbot HK, Aquino C, George A, Budd A, Brammer L, Langley G, Hall AJ, Fry A. Hospitalization rates and characteristics of patients hospitalized with laboratory-confirmed coronavirus disease 2019 - COVID-NET, 14 states, March 1-30, 2020. MMWR Morb Mortal Wkly Rep. 2020;69(15):458-464.

9. Almandoz JP, Xie L, Schellinger JN, Mathew MS, Gazda C, Ofori A, Kukreja S, Messiah SE. Impact of COVID-19 stayat-home orders on weight-related behaviours among patients with obesity. Clin Obes. 2020;10(5):e12386.

10. Sidor A, Rzymski P. Dietary Choices And Habits During COVID-19 lockdown: Experience from Poland. Nutrients. 2020;12(6):1657.

11. Zhang J, Wu W, Zhao X, Zhang W. Recommended psychological crisis intervention response to the 2019 novel coronavirus pneumonia outbreak in China: A model of West China Hospital. Precision Clinical Medicine. 2020; 3(1): 3-8.

12. Sharafi S, Garmaroudi G, Ghafouri M, Shabnam Akhoundzadeh Bafghi M. Ghafouri M. Tabesh Z. Alizadeh Prevalence of anxiety and depression in patients with overweight and obesity. Obes Med. 2020;17:100169.

13. Yılmaz C, Gökmen V. Neuroactive compounds in foods: Occurrence, mechanism and potential health effects. Food Res Int. 2020;128:108744 .

14. Pellegrini M, Ponzo V, Rosato R, Scumaci E, Goitre I, Benso A, Belcastro S, Crespi C, De Michieli F, Ghigo E, Broglio F, Bo S. Changes in weight and nutritional habits in adults with obesity during the "lockdown" period caused by the COVID-19 virus emergency. Nutrients. 2020;12(7):2016. 